\title{
Two new species of the genus Scathophaga Meigen, 1803 (Diptera: Scathophagidae) from Asia
}

\author{
Ава новых вида рода Scathophaga Meigen, 1803 (Diptera: \\ Scathophagidae) из Азии
}

\author{
A.L. Ozerov ${ }^{1}$, M.G. Krivosheina ${ }^{2}$ \\ А. $\Lambda$. Озеров ${ }^{1}$, М.Г. Кривошеина ${ }^{2}$ \\ 'Zoological Museum, Moscow Lomonosov State University, Bol'shaya Nikitskaya 2, Moscow 125009, Russia (ZMUM). E-mail: \\ ozerov2455@rambler.ru \\ 'Зоологический музей, Московский государственный университет им. М.В. Ломоносова, Большая Никитская ул., 6, Москва \\ 125009, Россия. \\ ${ }^{2}$ A.N. Severtsov Institute of Ecology and Evolution, Russian Academy of Sciences, 119071 Moscow, Russia. E-mail: \\ dipteramarina@rambler.ru \\ ${ }^{2}$ Институт проблем экологии и эволюции им. А.Н.Северцова РАН, Ленинский проспект, 33, Москва 119071, Россия.
}

KEYWORDS: Diptera, Scathophagidae, Scathophaga, new species, China, Russia.

КЛЮЧЕВЫЕ СЛОВА: Diptera, Scathophagidae, Scathophaga, новый вид, Китай, Россия.

ABSTRACT. Two new species, Scathophaga alashanica sp.n. and Scathophaga buryatica sp.n. (Diptera: Scathophagidae), are described and illustrated based on specimens from Inner Mongolia (China) and Buryatia (Russia). Characteristics for the differentiation of the new species from related species are given.

РЕЗЮМЕ. Описаны два новых вида мух из семейства Scathophagidae: Scathophaga alashanica sp.n. по материалам из Китая (Внутренняя Монголия) и Scathophaga buryatica sp.n. по материалам из России (Бурятия). Приведены иллюстрации и указаны признаки, отличающие новые виды от близких видов.

\section{Introduction}

During examination of the material from the collection of Scathophagidae in the Zoological Institute of the Russian Academy of Sciences, St. Petersburg, Russia (ZISP), two undescribed species of the genus Scathophaga Meigen, 1803 were recognized. The descriptions of these species are given below. Characteristics for the differentiation of the new species from related species are given.

The morphological terminology used in the descriptions follows McAlpine [1981], Cumming et al. [2009], and Stuckenberg [1999]. Dissected male genitalia were examined with a Nikon SMZ645 stereomicroscope and then photographed using an eTREK DCM900 digital camera attached in place of an eyepiece of monocular microscope. Resulting batches of images were processed with CombineZP software [Hadley, 2007], and editing of stacked images was performed in Adobe Photoshop.

\section{Descriptions of new species}

Scathophaga buryatica sp.n. Figs 1-4.

Holotype $0^{7}$, RUSSIA, East Sayan, Samarta $\left(52.0944^{\circ} \mathrm{N}\right.$, $101.1372^{\circ} \mathrm{E}$ ), $40 \mathrm{~km}$ NO of Mondy, 1.VIII.1965, Gorodkov (ZISP). Paratype $\sigma^{\prime}$, RUSSIA, East Sayan, Arshan $\left(51.9082^{\circ} \mathrm{N}, 102\right.$. $\left.4294^{\circ} \mathrm{E}\right)$, 1.VII.1965, Negrobov (ZMUM).

DESCRIPTION. Male. Length of body 5.2-6.2 $\mathrm{mm}$. Length of wing 4.8-5.8 $\mathrm{mm}$.

Head. Frontal vitta yellow, matt; face and gena yellow, whitish dusted; fronto-orbital plate, ocellar triangle, and postcranium blackish, greyish dusted. Setae: 3 orbitals, 4-5 frontals, 1 ocellar, 1 postocellar, 1 inner vertical, 1 outer vertical; 1 pair of strong vibrissae and 2-3 pairs of subvibrissae present. Postcranium covered with white hairs. Antenna black; postpedicel about twice as long as wide; arista black, bare. Palpus yellow, filiform, without long apical seta.

Thorax. Completely black, dense pale grey dusted. Acrosticals small in two rows, 2 postpronotals, 2 notopleurals, 1+2 supra-alars, 1+2 intra-alars, 2 postalars, and $2+3$ dorsocentrals. Proepisternum centrally and ventrally with whitish hairs, without strong setae ventrally. Proepimeron with whitish hairs. Anepisternum

How to cite this article: Ozerov A.L., Krivosheina M.G. 2019. Two new species of the genus Scathophaga Meigen, 1803 (Diptera: Scathophagidae) from Asia // Russian Entomol. J. Vol.28. No.1. P.102-106. doi: 10.15298/rusentj.28.1.18 

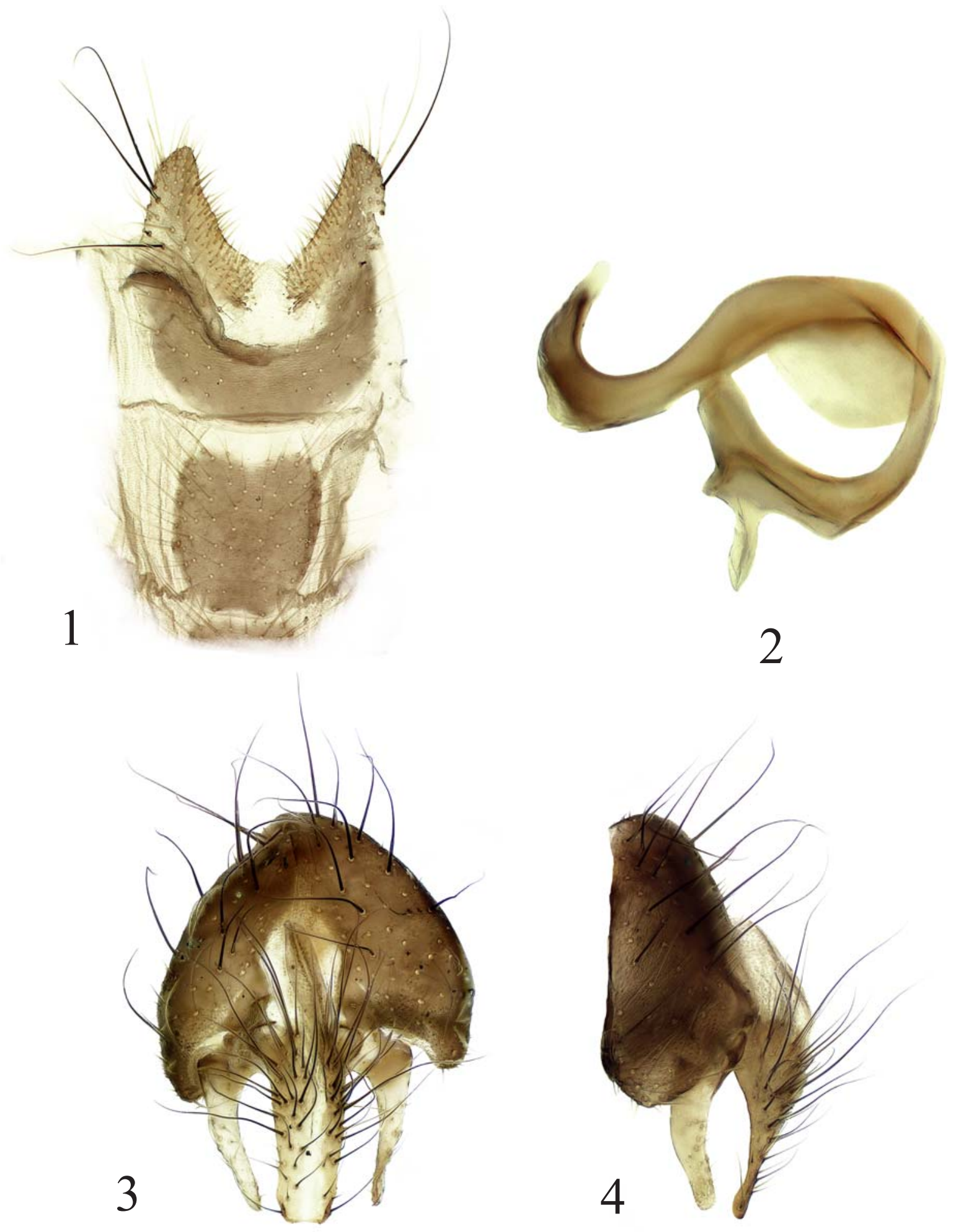

Figs 1-4. Scathophaga buryatica sp.n., HT O : 1 - sternite 4 (lower) and 5 (upper); 2 - aedeagus, lateral view; 3 - epandrium, cerci and surstyli, dorsal view; 4 - epandrium, cerci and surstyli, lateral view.

Pис. 1-4. Scathophaga buryatica sp.n., НТ ơ: 1 - стернит 4 (верхний) и 5 (нижний); 2 - эдеагус, сбоку; 3 - эпандрий, церки и сурстили, сверху; 4 - эпандрий, церки и сурстили, сбоку. 


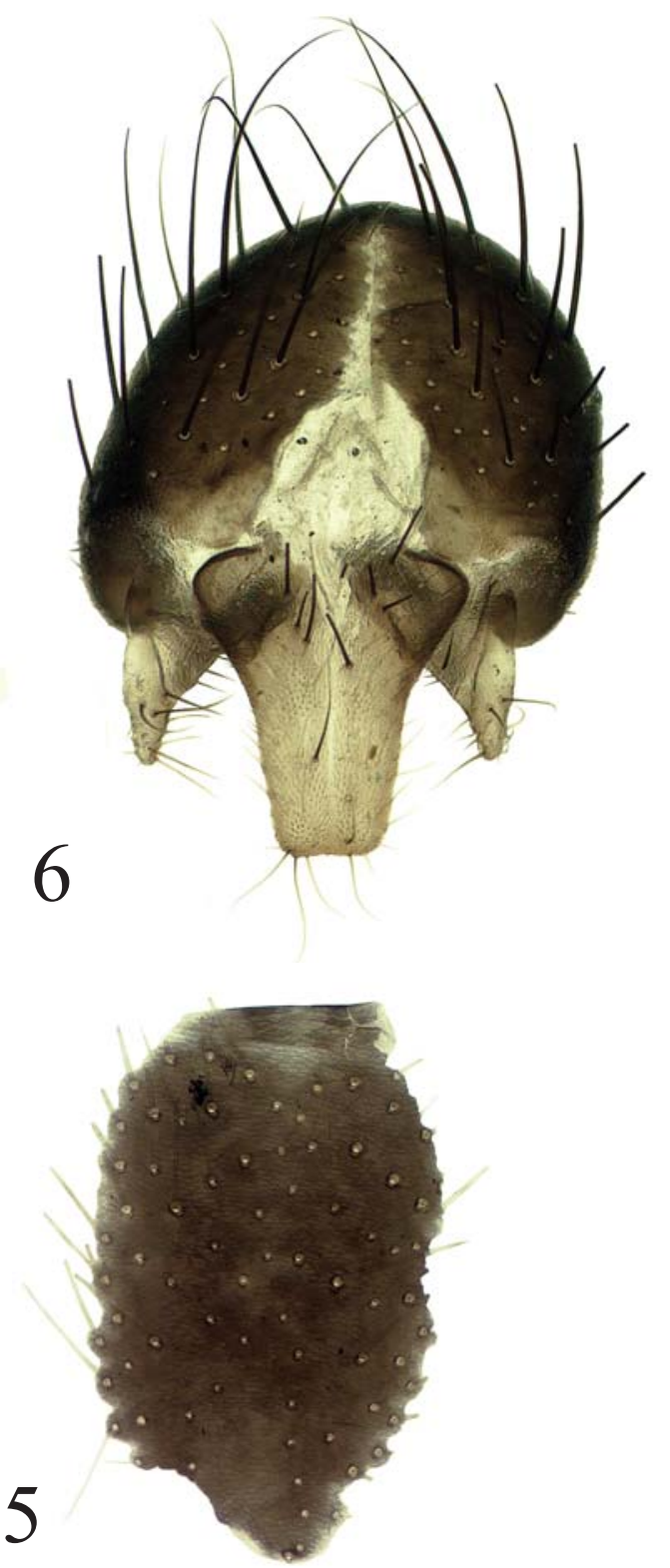

covered with hairs completely and with 3-4 strong setae along posterior margin. Katepisternum covered with hairs completely, with long whitish hairs posteriorly and one strong seta in posterodorsal corner. Postmetacoxal bridge absent. Scutellum greyish dusted, with a pair of strong basal scutellar and a pair of strong apical scutellar setae.

Legs. All coxae black, greyish dusted. All femora black, except $1 / 4$ or $1 / 5$ of yellow apex, greyish dusted. All tibiae and tarsi yellow. Fore femur covered with whitish and blackish hairs, without striking setae. Fore tibia with a row of posterodorsal setae, with 1-2 dorsal, 1-2 posterior, 1 preapical anterodorsal, 1 apical posterodorsal, 1 apical posterior setae. Mid femur with a row of anterodorsal setae, with 1 preapical posterodorsal and 1 preapical posterior setae. Mid tibia with 2 anterodor-

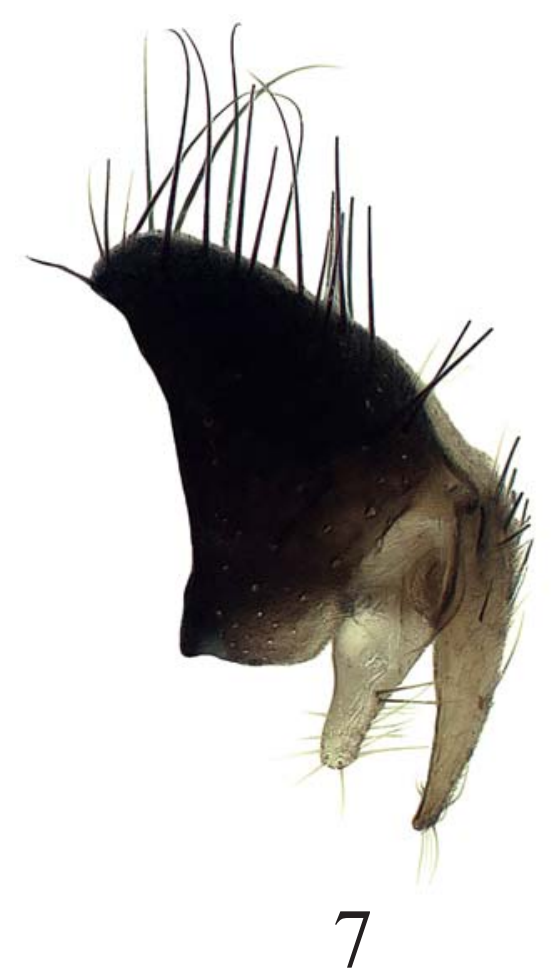

Figs 5-7. Scathophaga alashanica sp.n., PT O$^{7}: 5-$ sternite 4; 6 - epandrium, cerci and surstyli, dorsal view; 7 - epandrium, cerci and surstyli, lateral view.

Рис. 5-7. Scathophaga alashanica p.n., РТ $0^{7}: 5-$ стернит $4 ; 6$ - эпандрий, церки и сурстили, сверху; 7 - эпандрий, церки и сурстили, сбоку.

sal, 2 posterodorsal, and $0-1$ anteroventral setae, also with a ring of apicals. Hind femur with a row of dorsal/ anterodorsal setae. Hind tibia with 2-3 posterodorsal, 2-3 anterodorsal, 1 preapical dorsal, 1 preapical anterodorsal, and 2 apical anteroventral setae.

Wing clear, veins brownish. Vein $\mathrm{R}_{1}$ bare. Calypteres, including margins, whitish or yellowish. Halter yellow.

Abdomen black, greyish dusted, covered with whitish hairs. Male sternite 4 about 1.5 times as long as wide (Fig. 1). Male sternite 5 with little curved internally lobes, each with external long setae (Fig. 1). Cerci and surstyli as in Figs 3, 4. Aedeagus with curved apical part, with acrophallus and paraphallus forming ring (Fig. 2).

Female unknown. 


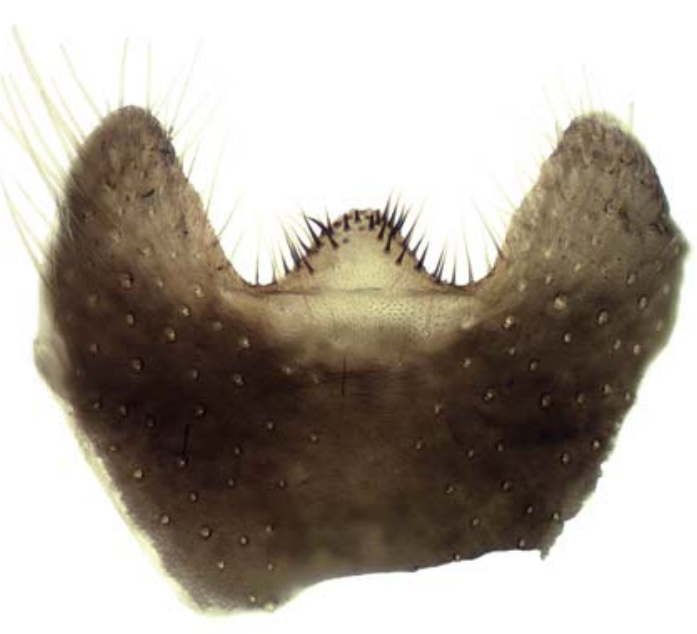

8
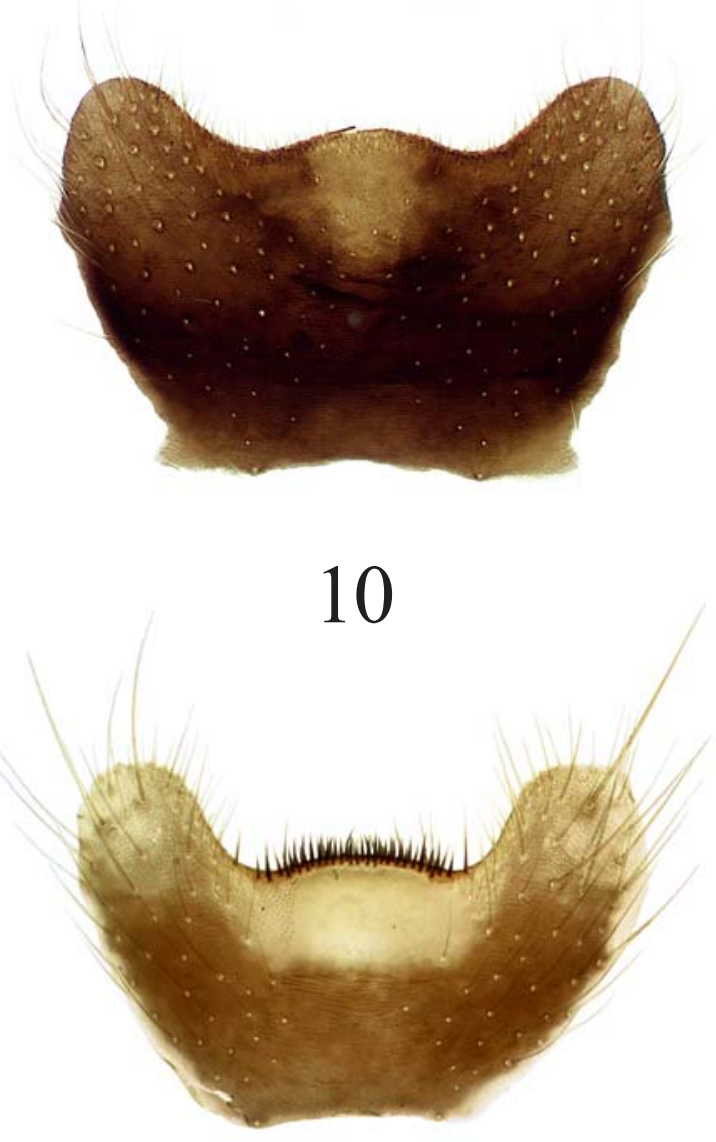

12

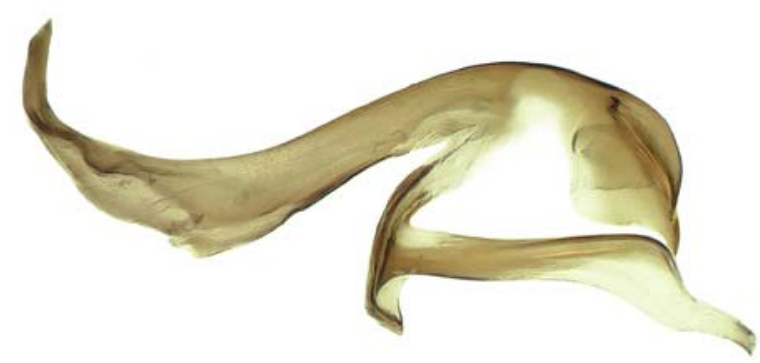

9
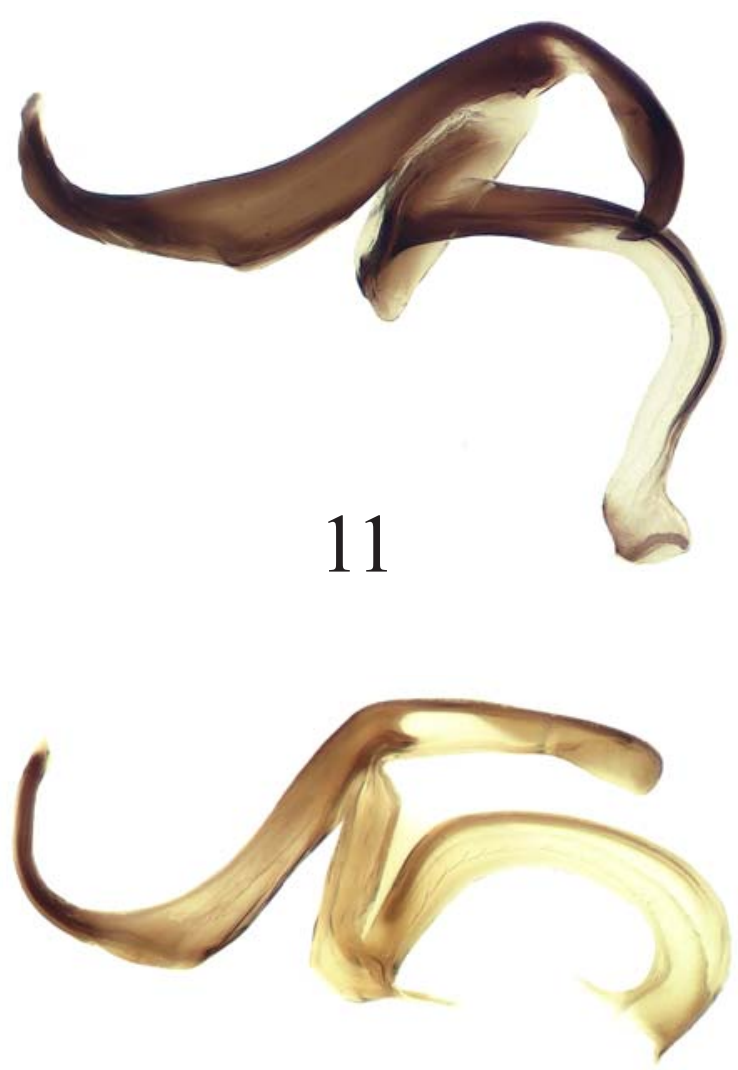

13

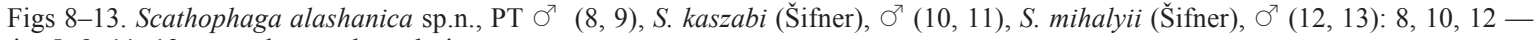
sternite 5; 9, 11, 13 - aedeagus, lateral view.

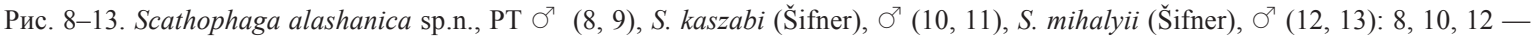
стернит 5; 9, 11, 13 - эдеагус, сбоку. 
NOTE. The new species differs well from the other species of Scathophaga by the structure of cerci and surstyli (Figs 3, 4), also aedeagus, which has specific form (Fig. 2).

DISTRIBUTION. Russia (Buryatia).

\section{Scathophaga alashanica sp.n.}

Figs 5-9.

Holotype O", CHINA, “Дын-юань-ин, с. Алашань” [Alashan or Alxa, $\left.38.8442^{\circ} \mathrm{N} 105.7050^{\circ} \mathrm{E}\right], 30 . \mathrm{V} .1908$, Kozlov (ZISP). Paratypes $1 \sigma^{\top} \sigma^{\top}, 2$, 2 , the same geographical label as the holotype, 29 and 30.V.1908 (ZISP, ZMUM).

DESCRIPTION. Male, female. Length of body 5.1$6.0 \mathrm{~mm}$. Length of wing 5.4-6.1 mm.

Head. Frontal vitta yellow, matt; face and gena yellow, whitish dusted; fronto-orbital plate, ocellar triangle, and postcranium blackish, greyish dusted. Setae: 3 orbitals, 3-4 frontals, 1 ocellar, 1 postocellar, 1 inner vertical, 1 outer vertical; 1 pair of strong vibrissae and 2 pairs of subvibrissae present. Postcranium covered with white hairs. Antenna black; postpedicel about twice as long as wide; arista black, bare. Palpus yellow, filiform, without long apical seta.

Thorax. Completely black, dense pale grey dusted. Acrosticals not differentiated than the other hairs on scutum, 2 postpronotals, 2 notopleurals, $1+2$ supraalars, $1+2$ intra-alars, 2 postalars, and $2+3$ dorsocentrals. Proepisternum centrally and ventrally with whitish hairs, without strong setae ventrally. Proepimeron with whitish hairs. Anepisternum covered with hairs completely and with 3-4 strong setae along posterior margin. Katepisternum covered with hairs completely, with long whitish hairs posteriorly and one strong seta in posterodorsal corner. Postmetacoxal bridge absent. Scutellum greyish dusted, with a pair of strong basal scutellar and a pair of strong apical scutellar setae.

Legs. All coxae black, greyish dusted. All femora black, except $1 / 4$ or $1 / 5$ of yellow apex, greyish dusted. All tibiae and tarsi yellow. Fore femur with whitish hairs, longer ventrally, with 4-5 dorsal setae in apical third. Fore tibia with 3-4 posterodorsal in apical half, 2 dorsal, 1-2 posterior, 1 preapical anterodorsal, 1 apical posterodorsal, 1 apical posterior setae. Mid femur with a row of anterodorsal setae, with 1 preapical posterodorsal and 1 preapical posterior setae. Mid tibia with 1-2 anterodorsal, 1-2 posterodorsal, 1 ventral (strong in female) and 1 preapical dorsal setae, also with a ring of apicals. Hind femur with a row of dorsal/ anterodorsal setae. Hind tibia with 2-3 posterodorsal, 2-3 anterodorsal, 1 preapical dorsal, 1 preapical anterodorsal, and 1 apical anteroventral setae.

Wing clear, veins brownish. Vein $\mathrm{R}$ bare. Calypteres, including margins, whitish or yellowish. Halter yellow.

Abdomen black, greyish dusted, covered with whitish hairs. Tergites $2-5$ in male and tergiters $2-6$ in female each with a row of marginal setae. Male sternite 4 almost twice as long as wide (Fig. 5). Male sternite 5 with short lobes, with short conical projection medially between both lobes (Fig. 8). Cerci and surstyli as in Figs 6, 7. Aedeagus as in Fig. 9.

COMPARISON. The new species is similar to $S$. kaszabi (Šifner, 1975) and S. mihalyii (Šifner, 1975) by the structure of cerci and surstyli, but differs easily by the shape of aedeagus (compare Figs 9, 11, 13) and of male sternite 5 (compare Figs 8, 10, 12).

DISTRIBUTION. China (Inner Mongolia).

Acknowledgements. The work was conducted within the state project No AAAA-A16-116021660077-3. We are very grateful to Dr. Olga Ovchinnikova (ZISP) and Mrs. Galina Suleymanova (ZISP) for the loan of the material of Scathophaga for study.

\section{References}

Cumming J.M., Wood D.M. 2009. Adult morphology and terminology // Brown B.V., Borkent A., Cumming J.M., Wood D.M., Woodley N.E., Zumbado M. (eds.). Manual of Central American Diptera. Vol.1. Ottawa: National Research Council Press. P.9-50.

Hadley A. 2007. CombineZM. Open source image processing software package for creating extended depth of field images. Available from: http://www.hadleyweb.pwp.blueyonder.co.uk/ (accessed 17 January 2011)

McAlpine J.F. 1981. Morphology and terminology-adults // McAlpine J.F., Peterson B.V., Shewell G.E, Teskey H.J., Vokeroth J.R., Wood D.M. (Coordinators). Manual of Nearctic Diptera. Vol.2. Ottawa: Research Branch. Agriculture Canada. Monograph 27. P.9-63.

Stuckenberg B.R. 1999. Antennal evolution in the Brachycera (Diptera), with a reassessment of terminology relating to the flagellum // Studia Dipterologica. Vol.6. S.33-48. 